\title{
Development of Khutbah Books: Media for Increasing Student Soft Skills in PAI Courses at Universitas Nahdlatul Ulama Blitar
}

\author{
Abdurrachman Sidik $^{(1)}$, Siti Uswatun Kasanah ${ }^{(2)}$, Zainal Rosyadi $^{(3)}$ \\ Universitas Nahdlatul Ulama Blitar, Indonesia \\ E-mail: (1)arachmansidik@unublitar.ac.id; ${ }^{(2)}$ sitiuswatun@unublitar.ac.id; \\ ${ }^{(3)}$ zainalrosyadi@unublitar.ac.id
}

Received: 15 November 2021; Revised: 25 November 2021; Accepted: 27 November 2021

\begin{abstract}
The purpose of this study is to conduct a Khutbah book as a medium for improving student soft skills in PAI courses at Nahdlatul Ulama University Blitar. The focus of this research is the development of the Khutbah book as a medium for improving student soft skills with content according to updated scientific and social developments. Using the Research and Development method developed by Borg and Gall which includes preliminary studies, research planning, design development, product testing, revision of limited field test results, extensive product testing, revision of wider field test results, feasibility test, final revision of test results feasibility, dissemination and implementation of the final product. Data were collected from the assessment of two experts through the Expert validation sheet and 57 students respondents through a student respondent questionnaire. Data analysis used qualitative and quantitative approach techniques. Data in the form of suggestions and criticisms from experts/experts and students were analyzed with a qualitative approach, while data on the feasibility of the Khutbah book and opinions regarding the suitability of the book were processed using a quantitative descriptive approach. Data analysis that the Khutbah book needs to be arranged in accordance with scientific and social developments in society. The results showed that the Khutbah book was suitable for use in the development of student soft skills.
\end{abstract}

Keywords: Khutbah Books; Soft Skills; PAI Courses; Higher Education

\section{Introduction}

Education in higher education is required to always prioritize quality outputs and have soft skills according to their expertise. Students as outputs need to be equipped with what is always needed in the field. In general, during lectures at college, they acquire hard skills, while a lot of evidence shows that the determinants of one's success are obtained outside of lectures. There are many shifts in the formation of graduate competencies, so comprehensive, effective and transformative learning is carried out towards outputs that have the knowledge, attitudes and skills so that they have the competitiveness of graduates. The results of this study are: (1) Friday Khutbah and Hari Raya Books;

(2) Soft Skills of Students in Higher Education.

Previous research has discussed that the Friday Khutbah is a strategic time to carry out da'wah, considering that Muslims consciously gather to perform Friday Prayer services starting with the Khutbah (Syah, 2017). In general, to equip prospective alumni to have da'wah skills. Considering that every male Muslim is obliged to carry out Friday prayers (Zahro, 2016). The delivery of the Friday Khutbah is generally carried out by bringing text or small notes below to the pulpit as a guide so that there are no mistakes in quoting the arguments. argument to be presented (Noor, 2020).

Meanwhile, the current research is developing a Khutbah reference book to make it easier for students, especially students and the general public, to get new reference books. The formation of graduate competencies needs to be carried out in a comprehensive, effective and transformative learning towards outputs that have the knowledge, attitudes and skills so that 
they have the competitiveness of graduates. As in Islam, there are two guidelines that are always referred to, the Qur'an and Hadith. Both contain teachings that guide humanity and the universe in a better and orderly direction (Lutfi, 2016) The development of the model is intended as an effort to expand the situation or situation in stages to a more perfect or more complete situation as well as better conditions (Kasanah, SU. Ansori, 2019) It is time for the transformation of Islamic education to be carried out, both from the curriculum and the development of scientific applications, including learning media (Kasanah, 2020). The ability to read by paying attention to the quality of reading and intonation in speech.

At the end of each semester, an evaluation is carried out by a team of lecturers who support Islamic Religious Education courses at the Faculty of Exact Sciences, Mechanical Engineering study program class A1 and the Faculty of Education and Social Sciences, Class B1 sports study program at Nahdlatul Ulama University, Blitar. These problems include the subject of Islamic Religious Education which is a general basic course that must be mastered by all students, to provide basic skills about the Islamic religion, so that the material, especially Khutbahs, needs to be adapted to the development of science and social conditions in society. Learning media in the form of a Khutbah book will assist in equipping the practice of carrying out the Khutbah.

Islam is one of the official religions with the largest adherents in Indonesia and even in the world (Kasanah, 2019) However, increasing human resources is very much needed, both knowledge, character and soft skills according to their respective fields of expertise. Elfindri (2011: 67) explains that soft skills are "skills and life skills, both for oneself, in groups, or in society, as well as with the Creator". In line with this definition, LaFrance (2016: 4) states that soft skills are defined as "personal and interpersonal behavior that develops and maximizes human performance (eg confidence, flexibility, honesty, and integrity)" which means that soft skills are "personal and interpersonal skills that develop and maximize one's performance in terms of self-confidence, flexibility, honesty and self-integrity. Peggy in Illah, states that "soft skills encompass personal, social, communication, and self management behaviors, they cover a wide spectrum: self awareness, trust- worthiness, conscientiousness, adaptability, critical thinking, organizational awareness, attitude , initiative, empathy, confidence, integrity, selfcontrol, leadership, problem solving, risk taking and time management". Meanwhile, (Sailah, 2008). Argues that soft skills are "a person's skills in dealing with other people (inter-personal skills) and skills in self-regulation (intra-personal skills) that are able to develop optimally one's performance (performance). " Soft skills attributes, thus include the values held, motivation, behavior, habits, character and attitudes.

Based on the definition above, three important notes are obtained, namely first, that basically soft skills are abilities that already exist in everyone, but can be maximized and needed in the world of work as a complement to hard skills abilities. Second, soft skills are divided into two types, namely: soft skills related to personal, for example the ability to control one's emotions, can accept other people's advice, be able to manage time, and always think positively; and soft skills related to intra-personal, for example the ability to relate or interact with other people, cooperate with other groups, and others. Third, that soft skills are also a complement to hard skills.

Through Khutbah activities, Muslims consciously listen to the process of transferring knowledge, information on Islamic religious law and advice to increase faith and become a better person, for all Friday Prayer congregations. So that the khutbah activity is not only a ceremonial which invalidates the conditions for the validity of Friday prayers. More than that, it is also hoped that listeners can understand, appreciate and apply Islamic religious law in their daily lives. If the Khutbah material delivered by the preacher is interesting, in accordance with new themes, delivered with appropriate intonation, then the moral message in the Khutbah will be easily accepted by the congregation, but if the intonation and delivery method is less interesting, boring and the Khutbah material is too lack of updates, then the Friday Khutbah only invalidates the conditions for the validity of Friday prayers, even listeners are sure to fall asleep easily.

The Indonesian population is scattered in rural and urban areas with various customs, ethnicities, cultures and religions (Kasanah, 2020). This causes the implementation of the Friday Khutbah to be tolerated using a variety of languages, namely Indonesian and some are using regional languages and some are even using Arabic. However, the text that includes the 
pillars of the Khutbah must still be used in Arabic. Regarding tolerance for the use of regional languages and Indonesian in delivering his Khutbahs, with the aim that it can be understood by the congregation in the area. The concept of understanding Islam in the archipelago continues to develop into a study in determining the policies of Indonesian Islamic leaders, such as from among scholars, academics, and government. The policies of leaders to be able to become transformative leaders are needed (Kasanah, 2020). Therefore, in shaping the harmonization of mankind, there are various backgrounds of religious understanding, tradition and culture. You can also find the implementation of the Khutbah using loudspeakers and even in different rooms using Plasma TVs so that the presentation of the Khutbah by the preacher can not only be heard but also seen by the congregation.

The Qur'an and Hadith in Islamic teachings are two things that are always the guidelines that are always referred to. Both contain teachings that guide humanity and the universe towards a better and orderly direction (Lutfi, 2016). Islam means "surrender, obedience, submission and peace". Prophet Muhammad SAW revealed that this religion has five main teachings, namely "Islam is marked by testifying that there is truly no God but Allah and Muhammad is the messenger of Allah, establishing prayer, paying zakat, fasting and performing Hajj for those who can afford it" (Ansori, 2019). The implementation of the Friday Khutbah apart from being an obligation for Muslims, has been carried out routinely. However, beginners do not spontaneously have the ability to deliver a Khutbah. This requires habituation in order to explore and cultivate the hidden potential.

To the best of the researcher's knowledge, this research is different and has never been studied by other researchers. Researchers found research results that are relevant to the theme of this research, namely: 1) The dialectic between religion that has moral and universal values with the culture and traditions of Indonesian society forms a typical Indonesian-style Islam which is commonly called Nusantara Islam. Nusantara Islam is legitimate from an epistemological point of view. Critical analysis of the Islam of the archipelago resulted in a mapping of which ones should be preserved and which ones should be deconstructed. Among the things that must be maintained is the Islamic spirit of the archipelago which is tolerant in diversity, appreciation of good traditions, and elasticity or not being rigid in reading religious texts. The things that must be deconstructed are al-Ghazali's doctrine in terms of being hostile to philosophy and natural science and the strong guard against myth and mysticism by the Islamic archipelago that hinders progress and civilization (Alma'arif, 2015).

In his research, Nur also explained that the form of delivering the Friday Khutbah at the Old Kendari Grand Mosque is to bring a text or just a small note below the pulpit as a guide so that there are no mistakes in quoting the arguments to be conveyed, using a voice or tone that high if there is a sentence of emphasis that must be considered as an important point in the text message, but occasionally low. Meanwhile, the topic in the discussion of the Friday Khutbah is an invitation to the importance of preparing provisions for life in the world as our preparation to meet the real life. This confirms that the Khotib needs to prepare notes and intonations that are appropriate and supportive in the implementation of the Friday Khutbah (Nur, 2020).

\section{Materials and Method}

This study uses the Research and Development (R\&D) model (Buana, VG; Kasanah, 2019). Developed by Borg and Gall which includes the following stages: preliminary study planning, design development, product testing, revision of limited field test results, testing product broadly revised the results of a wider field test, feasibility test, final revision of the results of the feasibility test (Sugiarta, 2017). In general, this research produces certain products and tests the effectiveness of certain products (Sugiono, 2012). This study uses research subjects for a limited test, namely semester 2 of the Indonesian Language Education Study Program Class B1 and B2. The research instrument used expert validation sheets as many as 2 lecturers and a student questionnaire of 60 students. This study uses quantitative descriptive analysis, in order to determine the quality of learning modules, increase student achievement, and student responses obtained from material experts and student responses in the form of quantity data converted to qualitative. The results of the assessment of the validator and student questionnaires can be seen that the feasibility of the Khutbah Book is analyzed by means of the Khutbah Book validation analy- 
Journal Of Development Research, 5 (2), November 2021, Pages 193-199

Table 1. Guidelines for Conversion of Total Average scores into five categories

\begin{tabular}{|l|l|c|c|}
\hline No & \multicolumn{1}{|c|}{ Scoring Range } & Score & Category \\
\hline 1 & $\mathrm{Mi}+1,50 \mathrm{Sbi}<\mathrm{X}$ & $\mathrm{A}$ & Very Good \\
\hline 2 & $\mathrm{Mi}+0,50 \mathrm{Sbi}<\mathrm{X} \leq \mathrm{Mi}+1,50 \mathrm{Sbi}$ & $\mathrm{B}$ & Good \\
\hline 3 & $\mathrm{Mi}-0,50 \mathrm{Sbi}<\mathrm{X} \leq \mathrm{Mi}+0,50 \mathrm{Sbi}$ & $\mathrm{C}$ & Fair \\
\hline 4 & $\mathrm{Mi}-1,50 \mathrm{Sbi}<\mathrm{X} \leq \mathrm{Mi}-0,50 \mathrm{Sbi}$ & $\mathrm{D}$ & Poor \\
\hline 5 & $\mathrm{X} \leq \mathrm{Mi}-1,50 \mathrm{Sbi}$ & $\mathrm{E}$ & Very Poor \\
\hline
\end{tabular}

sis, namely the book assessment is based on the results of validation by experts, on each module validation sheet, the validator writes the following assessment categories: Score 1: not good, 2: moderately good, 3: good, and 4: very good. The ratings are then averaged.

The data analysis technique used a qualitative and quantitative approach. Data in the form of suggestions and criticisms from experts/ experts and students were analyzed with a qualitative approach, while data on the feasibility of books and opinions regarding the suitability of books were processed using a quantitative descriptive approach. The instrument assessment guidelines use the guidelines proposed by Saifudin Azwar (Azwar, 2010). This type of research is to develop products based on trials and then revised to produce products that are suitable for use. Borg and Gall (Sugiono, 2012). State that development research is a process used to develop and validate products used in education and learning. The development model is defined as a conceptual design process in an effort to improve the function of the existing model, through the addition of learning components that are considered to be able to improve the quality of achieving goals (Sugiarta, 2017).

The development procedure by Borg and Gall (Borg and Gall, 1983: 775) which includes 10 steps as shown in the following Figure 1.

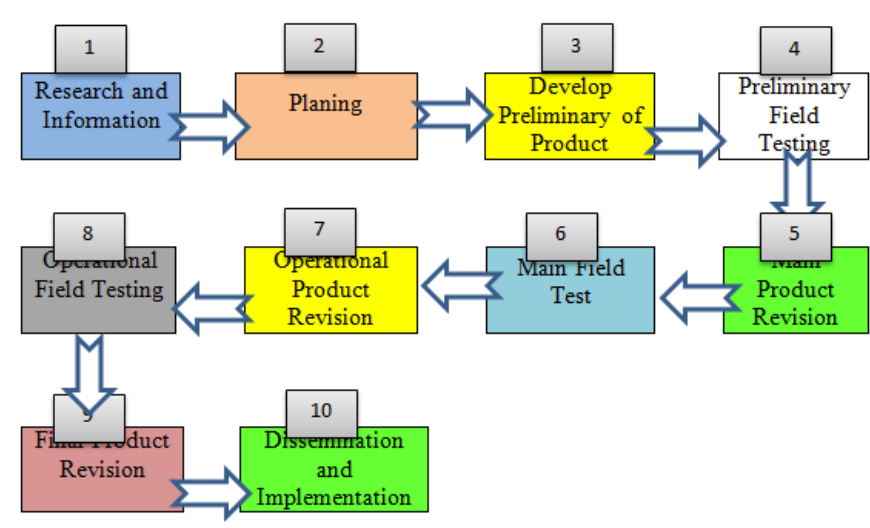

Figure 1: Development steps according to Borg and Gall

\section{Results and Discussion Research and Information Collecting}

At this stage, collect information by ensuring that lectures on Islamic Religious Education courses need to strengthen the skills of all students to be able to have the ability to find references for Khutbah books. The difficulty of students in finding references in completing assignments for Islamic Religious Education courses. None of the students have reference books or Friday Khutbah books with the latest material content.

Therefore, it is very important to have books that are in accordance with the theme of study in Islamic Religious Education courses, besides making it easier for students, community leaders and academics can also use them.

\section{Planning Research}

Conducting a literature study and determining the basic problems for analysis of the concepts to be taught, detailing according to the syllabus. Look for various sources that match the theme of the study. Furthermore, material classification is carried out, the target for implementation is a maximum of 8 months.

\section{Develop Preliminary of Product}

The development carried out is designing the Khutbah book. Covers the design of learning objectives, content of the Khutbah book to cover design. The content of the Khutbah book consists of 3 main parts, namely the introduction, Friday Khutbah and holiday Khutbah, adjusted to the lecture planning as follows: 1) Repentance to Reach God's Grace; 2) The meaning of a Taqwa; 3) Between piety and goodness in pilgrimage; 4) Faith and Degrees of Glory; 5) God and Spirituality; 6) Religion and Religiosity; 7) Al-Qur'an as the Inspiration of Civilization; 8) Ijtihad and the Sustainability of the Islamic Spirit; 9) Sunnah as Cultural Example and Inspiration; 10) Islamic morality in developing Culture and Science and Technology; 11) Islam and Cultural Arts; 12) Muslims and Work Ethic and 13) Religion and Harmony of Life, 14) Environment and Nature 
are God's Gifts; 15) Islam and Governance; 16) Preventing Religious Radicalism; 17) Islam Conserves women and 18) Religion and Corruption

These themes have been compiled in detail in a book, as a relatively new study, it is very easy for students and lecturers. The study meets the discussion in one semester.

\section{Preliminary Field Testing}

The product test that was developed before being used was carried out by a material expert (M.Subhan Ansori) who is a lecturer in the "Aswaja and NU-an" course at PTS with a master's degree and a linguist (Reditya Wempi Ansori) with a master's degree in Indonesian Language Education. The results of the limited product test are that the caver changes from blue to green.

\section{Main Product Revision}

The revision of the results of the limited product test is the first revision, according to the input of the material expert and linguist validator. Initially, the title of the book only stated "A Col-

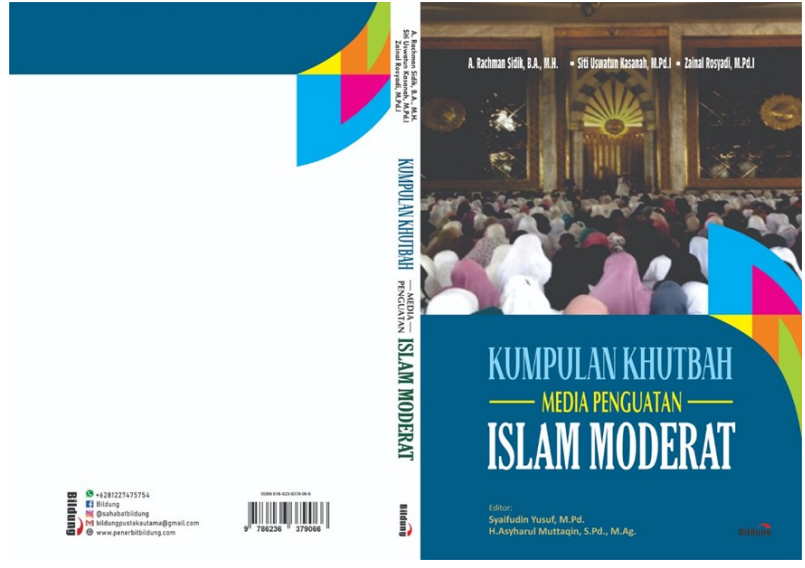

Figure 2 Cover Appearance Before and After Revision

lection of Friday Khutbahs" Then got advice from a linguist to sharpen the title of the book to be "A Collection of Khutbahs on Media Strengthening Moderate Islam" as stated on Figure 2.

\section{Main Field Test}

The product test was wider, carried out

Table 2. The feasibility in the field of material testing

\begin{tabular}{|c|c|c|c|c|}
\hline Category & Score & Highest Score & Lowest Score & Index (\%) \\
\hline Very Good & 342 & 90 & 88 & $88 \%$ \\
\hline Good & 83 & 85 & 83 & $84 \%$ \\
\hline Fair & 55 & 80 & 75 & $86 \%$ \\
\hline Poor & 0 & 0 & 0 & 0 \\
\hline Very Poor & 0 & 0 & 0 & 0 \\
\hline Total & $\mathbf{2 2 0 7}$ & $\mathbf{2 4 0 0}$ & $\mathbf{3 0 0}$ & $\mathbf{9 0 , 6 6}$ \\
\hline
\end{tabular}

Table 3. The feasibility of the Language and Image test field

\begin{tabular}{|c|c|c|c|c|}
\hline Category & Skor & Highest Score & Lowest Score & Index (\%) \\
\hline Very Good & 321 & 88 & 86 & $89 \%$ \\
\hline Good & 96 & 85 & 82 & $87 \%$ \\
\hline Fair & 62 & 83 & 76 & $84 \%$ \\
\hline Poor & 0 & 0 & 0 & 0 \\
\hline Very Poor & 0 & 0 & 0 & 0 \\
\hline Total & $\mathbf{2 1 7 9}$ & $\mathbf{2 4 0 0}$ & $\mathbf{4 8 0}$ & $\mathbf{9 0 , 7 5}$ \\
\hline
\end{tabular}

Table 4. The feasibility of the Presentation test field

\begin{tabular}{|c|c|c|c|c|}
\hline Category & Score & Highest Score & Lowest Score & Index (\%) \\
\hline Very Good & 548 & 90 & 87 & $90 \%$ \\
\hline Good & 147 & 85 & 81 & $84 \%$ \\
\hline Fair & 93 & 83 & 76 & $85 \%$ \\
\hline Poor & 52 & 0 & 0 & 0 \\
\hline Very Poor & 0 & 0 & 0 & 0 \\
\hline Total & $\mathbf{3 7 1 1}$ & $\mathbf{4 2 0 0}$ & $\mathbf{8 4 0}$ & $\mathbf{8 8 , 3 6}$ \\
\hline
\end{tabular}


Journal Of Development Research, 5 (2), November 2021, Pages 193-199

Table 5. The feasibility of the Display test field

\begin{tabular}{|c|c|c|c|c|}
\hline Category & Score & Highest Score & Lowest Score & Index (\%) \\
\hline Very Good & 242 & 89 & 86 & $89 \%$ \\
\hline Good & 34 & 85 & 80 & $84 \%$ \\
\hline Fair & 24 & 72 & 60 & $85 \%$ \\
\hline Poor & 0 & 0 & 0 & 0 \\
\hline Very Poor & 0 & 0 & 0 & 0 \\
\hline Total & $\mathbf{1 4 1 8}$ & $\mathbf{1 5 0 0}$ & $\mathbf{3 0 0}$ & $\mathbf{9 4 , 5 3}$ \\
\hline
\end{tabular}

in small groups of 9 students, divided into three groups, namely 3 students with a high level of understanding, 3 students with moderate levels, and 3 students with low levels. The students were asked to study Islamic Religious Education courses by using modules, they provided input on the Khutbah book that was developed. All aspects of the assessment are material 90.66\%; language and images $89.75 \%$; presentation of $78.75 \%$ and display as much as $89.56 \%$ answered very well.

Thus, from all aspects, namely aspects of material, language and images, presentation and display shows very well, it can be concluded that the module book is feasible to use.

This is based on material validation of 90.66 (very good), language and images of 89.75 (very good), presentation of 88.75 (very good), display of 92.56 (very good) also the results of student responses with an average score of 88.5 (very good).

\section{Operational Product Revision}

The revision of the results of the extensive field test was based on the responses of 12 students who conducted the field test by changing some of the main parts of the writing procedure.

\section{Operational Field Testing}

The results of the product design feasibility test in the actual class, namely Indonesian Language Education Class A and Indonesian Language Education $\mathrm{B}$, have obtained information on the feasibility of this Khutbah book shown in Tables 2, 3, 4 and 5 .

Based on the results of the feasibility test in Table 2, the material field obtained a score of 2,207 which was in the score range $>1875$ in the very good category. Judging from the Index (\%) obtained by $90.66 \%$, it shows that in terms of material it is very good so it is feasible to be used as a module book.

Based on the results of the feasibility test in the field of language and images in Table 3, it obtained a score of 2,179 which was in the score range $>1875$ in the very good category. Judging from the Index (\%) obtained by $89.75 \%$, it shows that in terms of language and images it is very good so it is worthy to be used as a book.

Based on the results of the feasibility test in the field of presentation in Table 4, it obtained a score of 3,711 which was in the score range $>1875$ with a very good category. Judging from the Index (\%) obtained by $88.36 \%$, it shows that in terms of presentation it is very good so that it is feasible or easy to understand.

Based on the results of the feasibility test in Table 5, the field of view obtained a score of 1,418 which was in the score range $>1875$ with a very good category. Judging from the Index (\%) obtained by $94.53 \%$, it shows that in terms of the appearance of the book it is very good so it is feasible to use.

From the written test analysis, it was found that 60 students were given a written test before they read the Khutbah book, the result was 38 students who scored above 75 . This shows that $62.5 \%$ got a complete score. This has not shown completeness in learning, because those who score more than 75 have not reached $85 \%$ of students.

Then after they studied the Khutbahl book, the test was carried out again. The results of the 2nd test were obtained as many as 57 students who scored above 75 . This means that as many as $88.6 \%$ of students obtained complete results. From these results, it can be said that learning has reached completeness, because those who get scores above 75 are more than $85 \%$ of the total students.

\section{Final Product Revision}

The final revision of the feasibility test was carried out according to the input from the results of the feasibility test carried out on 2 class students totaling 60 students. So that in terms of material, language and images, presentation and display become feasible to be widely used. 


\section{Dissemination and Implementation}

Dissemination and Implementation of the final product disseminated the results of the research on the development of this supporting book in international journals and the publication of a book with the title "Selection of Khutbahs on Media Strengthening Moderate Islam" for the public to know.

\section{Conclusion}

The Based on the results of research and discussion, the following conclusions are obtained: 1) the availability of appropriate Khutbah books in lectures, and the development of supporting books for Islamic Religious Education courses is urgently needed. 2) The results of the study indicate that the module is feasible to be used as a supporting book in Islamic Religious Education courses. Based on the results of material validation of 91.96 (very good), language and images of 90.75 (very good), presentation of 88.66 (very good), display of 94.53 (very good) also the results of student responses with the average score is 86.6 (very good).

\section{References}

Alma'arif, A. (2015). Islam Nusantara: Studi Epistemologis dan Kritis. Analisis: Jurnal Studi Keislaman, 15, 265-292.

Ansori, M. S. dkk. (2019). Meningkatkan Pemahaman dan Ketrampilan Ibadah Haji bagi Peserta Didik, Guru dan Wali Murid melalui Pembelajaran Praktek Manasik Haji untuk Anak Usia Dini. JPPNu: Jurnal Pengabdian Dan Pemberdayaan Nusantara.

Azwar, S. (2010). Reliabilitas dan Validitas. Pustaka Pelajar.

Buana, VG; Kasanah, S. (2019). Jurnal Penelitian Inovasi Pembelajaran, . 4(2), 1-79.

Kasanah, SU. Ansori, M. (2019). Development of Islamic Nusantara Course Module at Universitas Nahdlatul Ulama Blitar. Journal of Development Research, 3(3), 69-74.

Kasanah, dkk. (2020). Book Design of Online Based Islamic Education Subjects at the Universitas Nahdlatul Ulama Blitar. Journal of Development Research, 4(1), 76-81.

Lutfi, K. M. (2016). Islam Nusantara; Relasi Islam dan Budaya Lokal. Jurnal Shahih, I(Juni).

Noor, M. (2020). Penguatan Dakwah Melalui Pesan Khotbah Jumat Di Masjid Raya Lama. AlQolam, 26(1).

Nur, M. (2020). Penguatan dakwah melalui pesan khotbah jumat di masjid raya lama kendari. 181-190.
Sailah, I. dkk. (2008). Pengembangan Soft skills dalam Proses Pembelajaran di Perguruan Tinggi. an Tinggi, Departemen Pendidikan Nasiona.

Sugiarta, N. S. (2017). Pengembangan Model Pengelolaan Program Pembelajaran Kolaboratif untuk Kemandirian Anak Jalanan di Rumah Singgah. Disertasi. SPS UPI.

Sugiono. (2012). Metode Penelitian Kuantitatif, kualitatif, dan $R \& D$. Alfabeta.

Syah, S. M. N. (2017). Strategi Peningkatan Mutu Calon Guru PAI Melalui Pengembangan Soft Skill Di Peguruan Tinggi. Jurnal Elementari, 5(2).

Zahro, A. (2016). Khutbah Jum'at Sebagai Media Dakwah Strategis. Jurnal Dakwah Dan Komunikasi Islam, 2(1), 73-84. 